\title{
Impacts of 2010 Flood and GIS Mapping \\ (A Case Study of UC Shore Kot) DI Khan, KP Province \\ Pakistan
}

\author{
Mubashir Mehmood* and Muhammad Yaseen \\ ${ }^{1}$ Institute of Geology, University of the Punjab, Pakistan \\ 2Department of Geology, Abdul Wali Khan University Mardan, Pakistan
}

*Corresponding author: Mubashir Mehmood, Institute of Geology, University of the

Punjab, Lahore Pakistan, Tel: 00923153066061; Email: mubashirmehmood94@gmail.com

\section{Research article}

Volume 2 Issue 3

Received Date: April 04, 2018

Published Date: May 09, 2018

DOI: $10.23880 /$ jenr-16000130

\section{Abstract}

Flood is one of the devastating natural hazards that have a great geological, environmental, social and economic impact on a society and an area. This research present a brief analysis of dreadful impacts of 2010 flood in Shore Kot area, DI Khan KP province Pakistan which is caused by enormous rain in monsoon season which resulted in serious monetary damage and fatalities. Flood hazard mapping and flood shelters suitability analysis are vital elements in suitable land use scheduling for flood-prone areas. Pakistan is the one of those countries which are most affected by natural hazard and especially flood. The 2010 flood in Pakistan was described as the worst environmental disaster in Pakistan's history. In 2010 a devastating flood occurs in various places in Pakistan. Shore Kot area (DI Khan Kpk. The study area is vulnerable place to flood hazard. The main cause of flood in study area was heavy Monsoon rainfall and Noose water. There was lack of adequate warning system to inform people about flood, so that they could evacuate in time. The government also did not help the flood victims in evacuation. The procedure for Relief distribution suffered from favoritism by political leaders and mostly influential people had access to relief. The financial support to the flood victims was insufficient for rehabilitation. The whole communication system was disturbed during flood 2010.Roads were washed away and many people remained in the flooded area. Based on the results of this case study for Shore Kot area DI Khan District KP province, it can be concluded that geospatial technology provides the best potential to analyse and provide results required for prompt and effective decision-making on floods. This comprehensive flood hazard and flood shelters model developed in ArcGIS can be easily handled by novice GIS users. Remote sensing is an efficient tool for flood mapping and suitability analysis and can be useful for emergency response and disaster preparedness. Based on the results of this study for Shore Kot area DI Khan district KPK, it can be concluded that the study area is one of the most affected area and is still vulnerable to flood because of its geographic location. Remote sensing and GIS technology can provides the potential tool for prompt effective decision-making and management on flood.

Keywords: GIS; Flood; Hazard; Pakistan; Impacts 


\section{Journal of Ecology \& Natural Resources}

\section{Introduction}

With respect to other continents Asia is most populated beside this it is also ranked on top among most affected by natural disasters especially the flood. As natural disasters increasing with time throughout the world, most of the Asian countries are most reliable to natural hazards like floods, earthquakes due to their geographical instability. These natural hazards directly causing loss of life, infrastructure instability and destruction and decline in economy. Nearly 60,000 people were killed in floods only during the period 1994-2004 in Asia and accounted for one third of 1,562 flood disasters worldwide [1]. Flood is one of the most damaging natural hazard affecting live and property than any other disaster [2] and one of the utmost frightening natural hazards for the human societies [3]. Floods and other climate related natural disasters have been increasing due to climate changes and also increasing in intensity it is also increasing in size and frequency due to human activities in the upstream section of the river system [4]. A flood is a runoff of an expanse of water that immerses the land. Pakistan is one of the most vulnerable countries to natural hazards worldwide [5] and is exposed to several hazards such as floods, earthquake, landslides and droughts, but floods has been most common issue causing immense damages to lives and properties [6]. Pakistan has varying geography with Northern alpine enclosed with glaciers and Sothern plains along with the Arabian Sea. The five major rivers Indus and its tributaries, Jhelum, Chenab, Sutlej and Ravi are flowing through in Pakistan from south to north parts [7]. The frequency of damages of urban flood is increasing with the investment and growth in urban areas. Flash floods that happen in natural stream as a consequence of localized extreme rains in hills and semi hilly areas have really shown their potential of damage in the few previous years in the Pakistan [8]. The chief cause of continuity of floods in Pakistan is heavy intense rainfall in the river catchments that is occasionally increased by the snowmelt flows that final result into floods particularly in the season of monsoon. Sporadically monsoon currents initiating in the Bay of Bengal result in destructive and harsh floods in some or mostly all the river of Indus system [9]. The Province Khyber Pakhtunkhwa is the smallest Province of Pakistan in terms of geographic area; it is $9.4 \%$ of the country's total area. Khyber Pakhtunkhwa covers an area of 74,521 sq. $\mathrm{km}$ and is located on both banks of the river Indus and stretches from the Himalayas in the north to deserts of DI Khan in the south, where it is bordered by the Baluchistan and Punjab provinces.

There are two major river systems in KP (i) The Indus River, which forms the boundary with Punjab and passes from Attock to Dera Ismail Khan (Figure 1) in the south.

(ii) River Kabul flows down to join the Indus River from Afghanistan. Rainfall in KP generally occurs in two distinct crop-growing seasons: rabbi (winters, December - March) and kharif (summers, June - September).

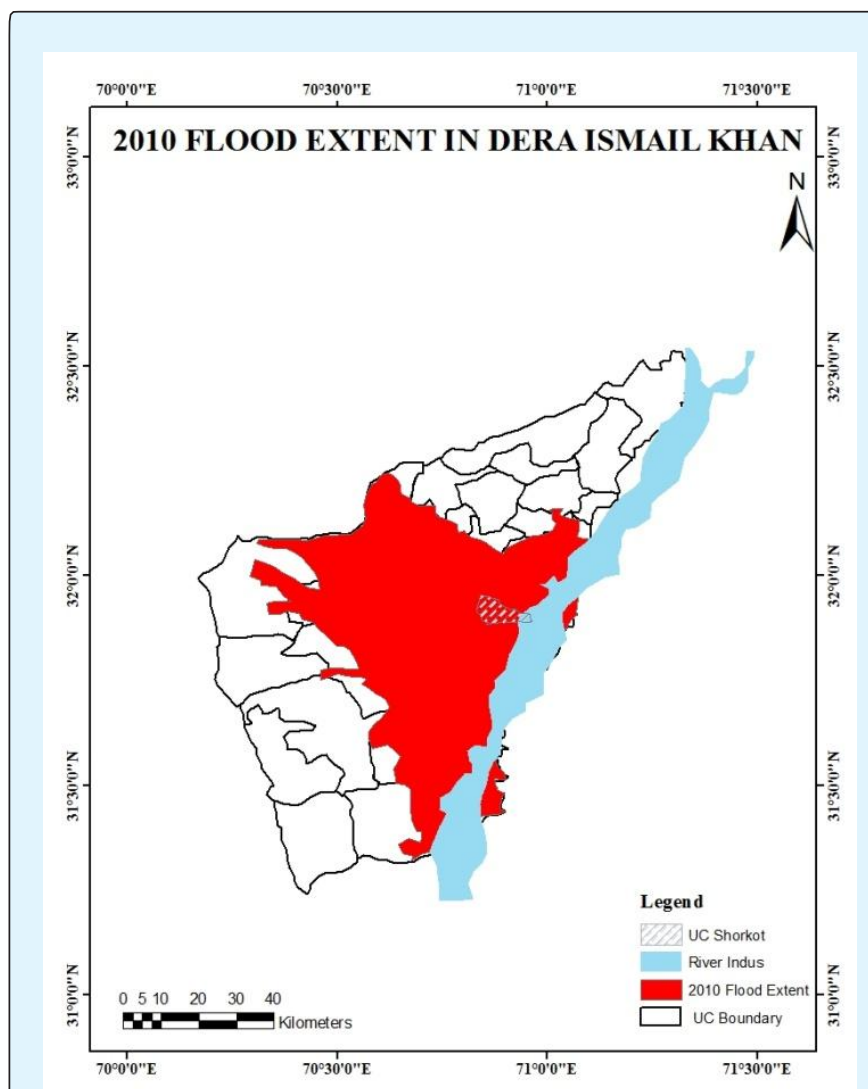

Figure1: Showing flood extensions in DI Khan with study area on River Indus bank.

Normally the monsoon arrives in first or second weeks of June. During the monsoons riverine floods that occur in rivers Kabul, Swat and Indus tend to impact the populated districts of central and western KP, while flash floods also occur astride these rivers, sometimes resulting in colossal losses. The floods in KP are generally caused by heavy concentrated rainfall in the catchments of River Indus, river swat and river Kabul during the monsoon season, which are also augmented by snowmelt flow. Major floods occur in late summer (July to September) when the South Asian region is subjected to heavy monsoonal rains. Major floods in the province have occurred in 1976, 1982, 1988, 
2005, 2006, 2007 and 2010. Flash floods are experienced commonly in Swat, Upper and Lower Dir, Chitral, Shangla, Kohistan, Peshawar, Mardan, Kohat and DI Khan [10]. Aim of the present study is to map flood hazard zone in UC Shore kot DI Khan area using Arc Gis, impacts of flood and proposed flood shelters. This study also attempts to exploit the devastating effects of 2010 flood in said area.

\section{Methodology}

\section{Study Area}

The DI Khan district is situated on the west of the Indus River. The study area is UC Shore Kot, within tehsil and district Dera Ismail Khan (Figure 2). It is geographically placed in North East of D.I Khan district and has a population of about 28,516 persons. The study area is hot in the summer and mild to warm in winter and is located close to the Indus River. The local respondent says the area has been named as Shore Kot as it is located on the bank of River Indus. The study area comprises six villages and experienced flood in months of July (last week) and August 2010. Heavy rainfall and water from Suleiman Mountains, called 'Noose' water (in local language) were the main causes of flood 2010 in the study area.

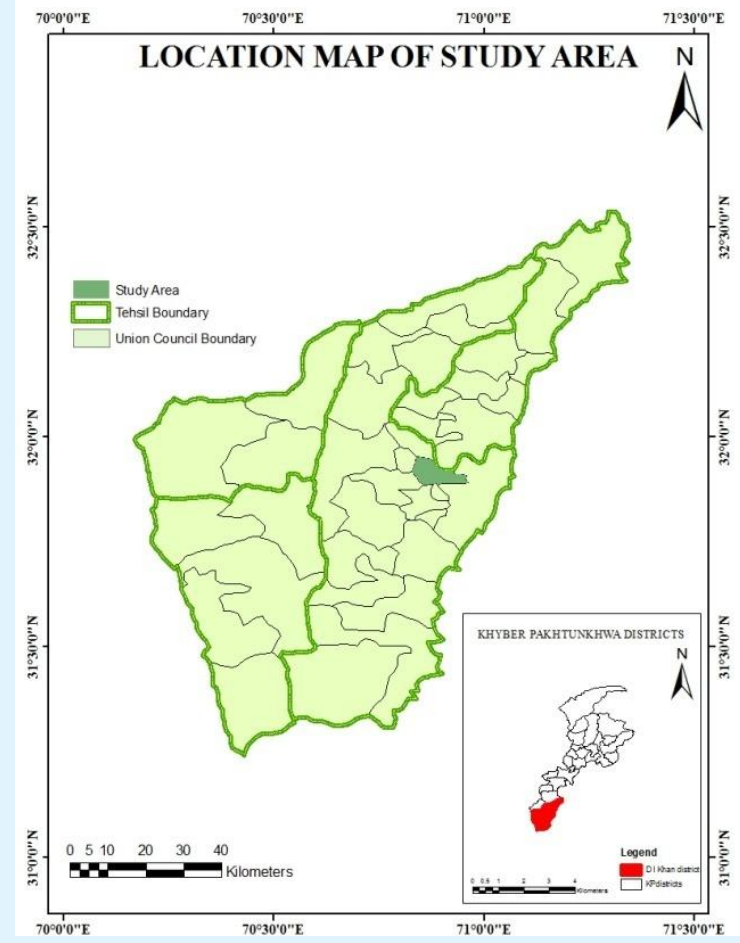

Figure 2: Location of the study area showing Shore Kot area (DI Khan) in red and blue.

\section{Data Collection}

After the selection of study area, a detailed plan for collection of data was prepared (Figure 3). Two types of data were collected i.e., Primary and secondary data.

Primary data: Primary data was collected through questionnaire survey and general observations.

\section{Sampling Frame}

Random sampling method was applied to collect relevant data through questionnaire survey. Out of six villages in UC Shorkot, most affected three villages namely Shorkot, CRBC colony and Himat were selected for field survey. Total 60 questionnaires were filled during field survey (20 from each village). The questionnaires with both open ended and close ended questions were used as a tool for data collection.

Secondary data: Secondary data was collected from various sources such as research articles and reports, District Census Report and concerned offices.

\section{Data analysis}

Data collected was analyzed, arranged and presented with the help of statistical techniques, computer software, and cartographic techniques. Results were presented in the form of statistical diagrams i.e., pie graph, bar graph, tables and maps generated through Arc Gis 9.3 version. Conclusions were made on the basis of results obtained by the analysis of data.

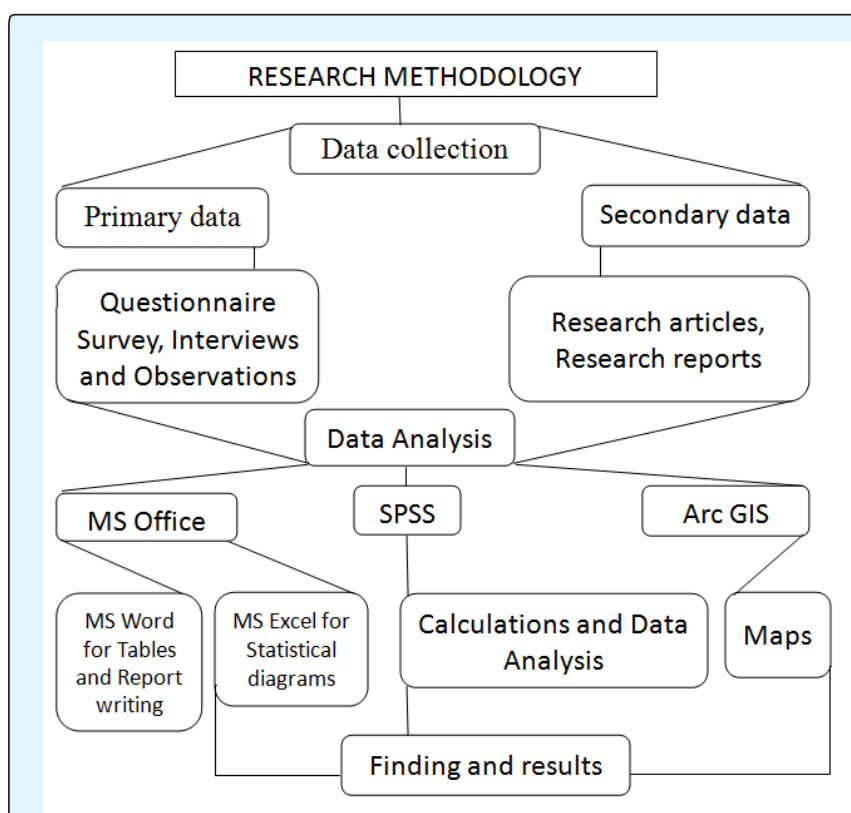

Figure 3: Out flow chart showing research methodology. 
Analysis of gained data were based on a standard questionnaire a total of 60 locals were interviewed in the present study. The reported interview were then analyzed in MS Excel and presented in Figure 4, a number of 58 male people were interviewed and 42 females out of total 60 respondents.

\section{Gender of respondents}

\section{Male Female}

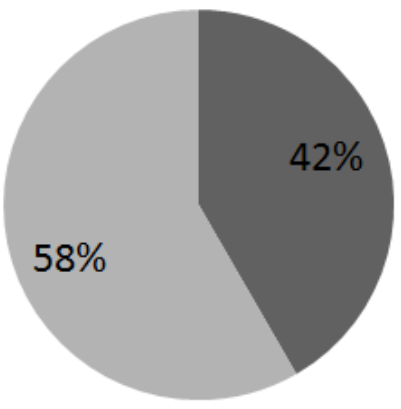

Figure 4: Showing gender of the respondents.

The respondents interviewed in this research were mostly of middle age also a few with age 60 and above Figure 5.

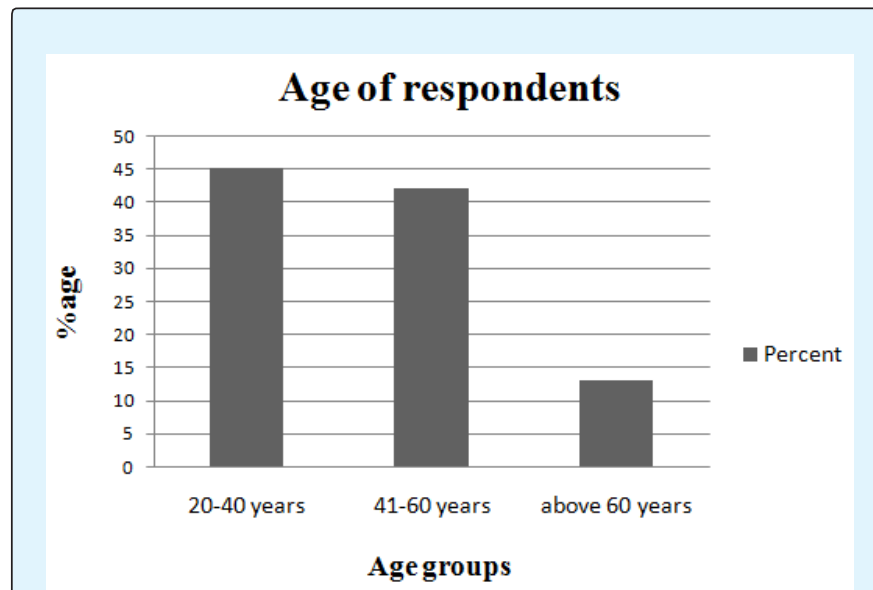

Figure 5: Showing age of the interviewers.

The study area is a less developed area having a low literacy rate. The people in the area are not interested towards education therefore mostly people are uneducated. Respondents education status as shown in Figure also reveals maximum interviewer were illiterate while only a few people have higher education (Figure 6).

\section{Education status of Respondents}

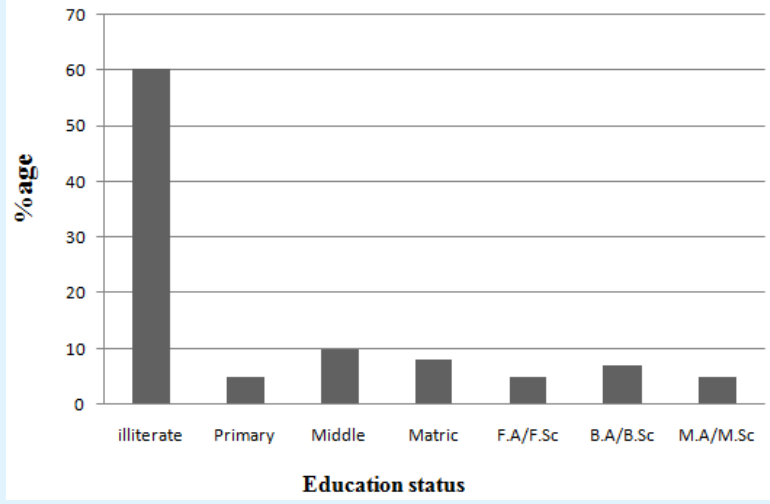

Figure 6: Showing education status of the local people in Shore Kot area.

The female interviewer in this research were all house wife beside men's a few were governments servants, some people were farmers, a few have their own shops and a number of five interviewers were students (Figure 7).

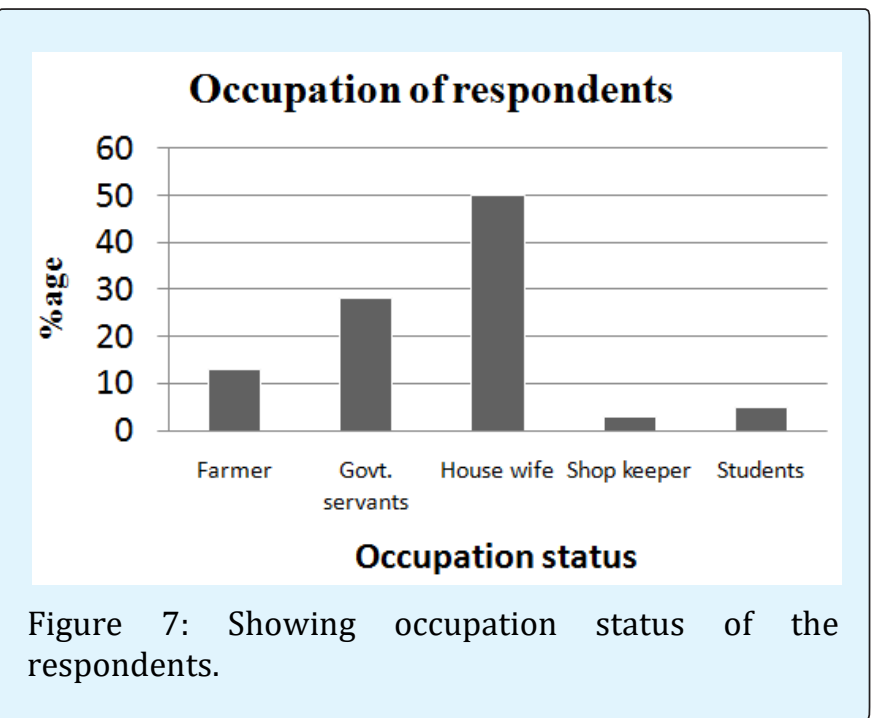

Family status of the interviewer as shown by Figure were majority living in joint family according to the local traditions most people live in joint family while $47 \%$ people were living in single family (Figure 8). 


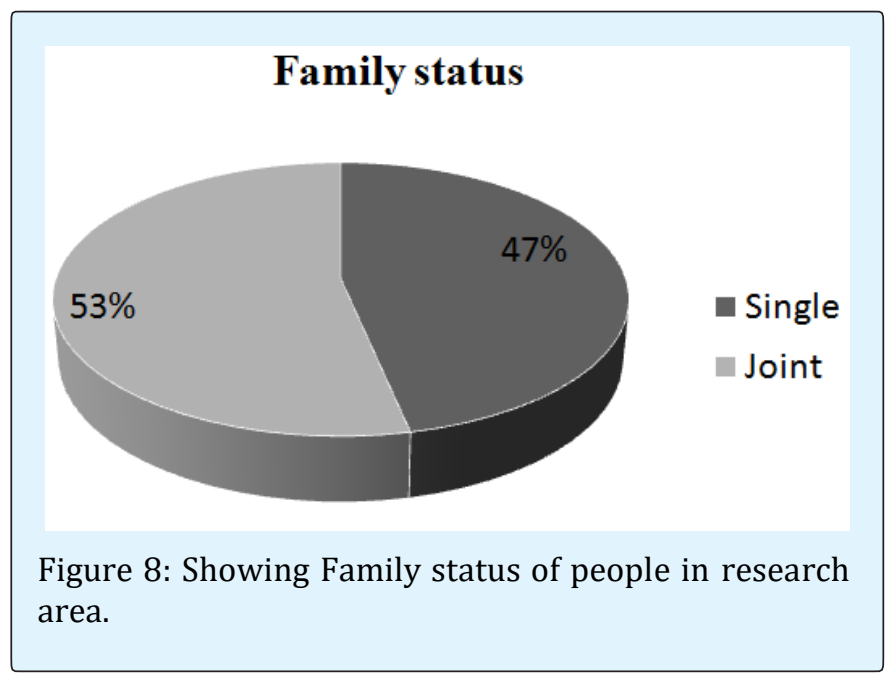

Maximum recorded people in a family in this research is above 15, while majority people lives in a family consists of 6-10 family members. The lowest recorded number in a family is 1-5 (Figure 9).

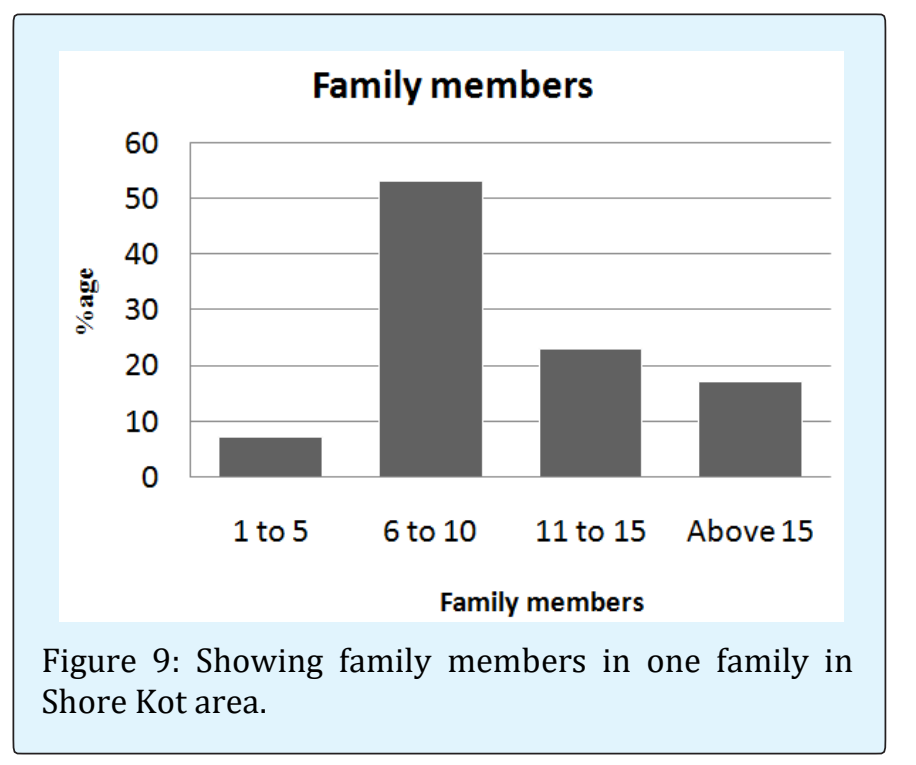

The locals were also asked about their time interval and regularity of flood occurrence in the residence area. The outcomes Figure shows majority people says that flood is a natural phenomenon and does not have any regularity but occurs when there is sudden change like mostly rainfall in monsoon season or very melting of glaciers. A few people suggest that in Shore Kot area flood occurs every year in monsoon season in a regular interval (Figure 10).

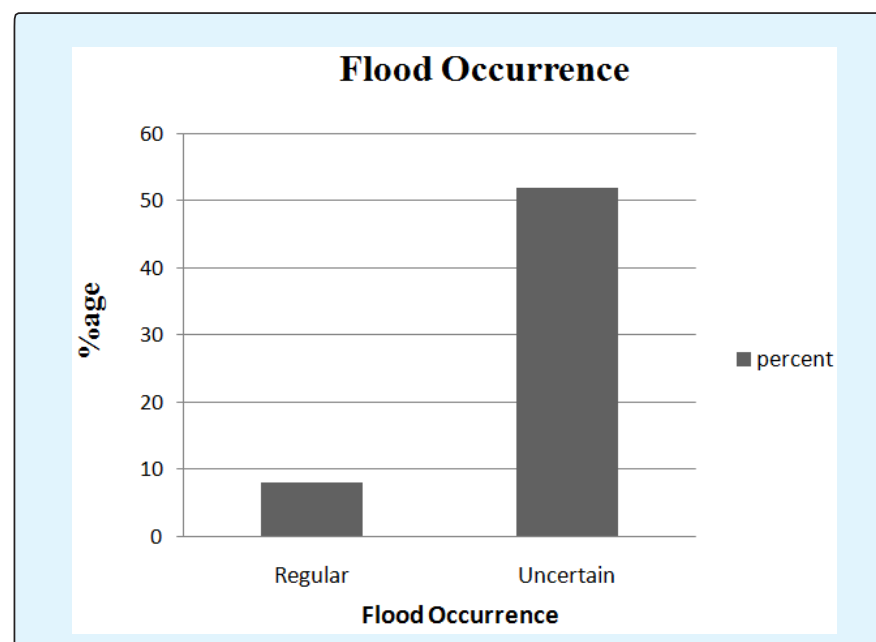

Figure 10: Showing flood occurrence pattern.

Most important question asked was about the cause of 2010 flood. In Pakistan there is sometime heavy and continuous rain fall up to few days in monsoon season. Most of the interviewers from Shore Kot area says that major cause of 2010 flood was the heavy rain fall which results in out bank flow of the River Indus causing a devastating flood. A few other reasons according to the locals were damaged canal, Noose water and river water but according to most of the local residents these are not the valid reasons beside heavy rainfall was a major cause of the 2010 flood in Shore Kot area (Figure 11).

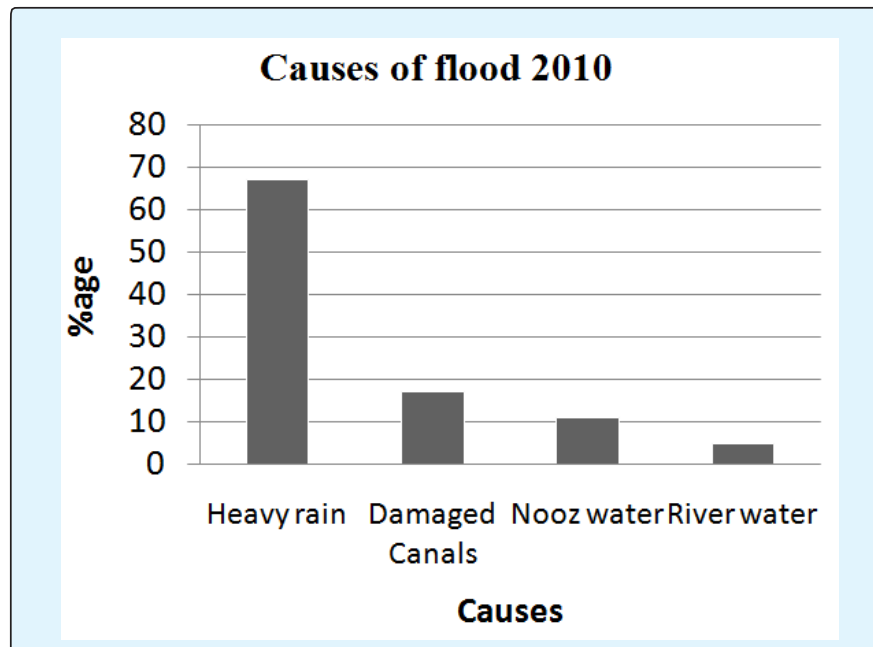

Figure 11: Showing causes of 2010 flood in study area.

Regarding the intensity of the 2010 flood in Shore Kot area majority (60\%) people says that the flood was more 
intense in destruction as compared to the last flood that occurs in the area beside $40 \%$ people did not give suggestion regarding intensity of flood (Figure 12).

\section{Flood intensity as compared to last flood}

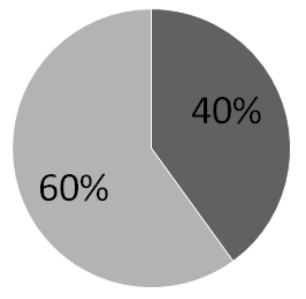

- High

No answer

Figure 12: Showing intensity of 2010 flood as compared to past floods.

The local residents were interviewed about any sort of alarm about occurrences of flood. $57 \%$ people say that they were warned through alarm on loudspeaker before flood occurrence. While rest of people says that they neither were completely unaware of flood occurrence nor were they warned through any alarm. The locals also says that no governmental or any NGO has warned the local people before flood. They were only warned through some local people a day before the flood (Figure 13).

\section{Warning before flood 2010}

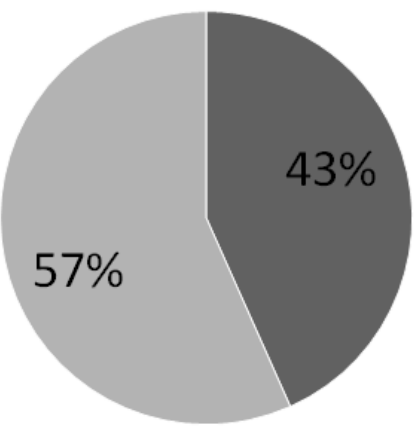

Yes

No

Figure 13: Showing whether peoples were warned before flood or not.

With the occurrence of flood the water flow towards land and most of time water stands on land for few days. In this regard the locals of Shore Kot village were asked about stagnancy of water in the area. Majority of the people says that water was standing in Shore Kot for about 20-40 days after the flood (Figure 14).

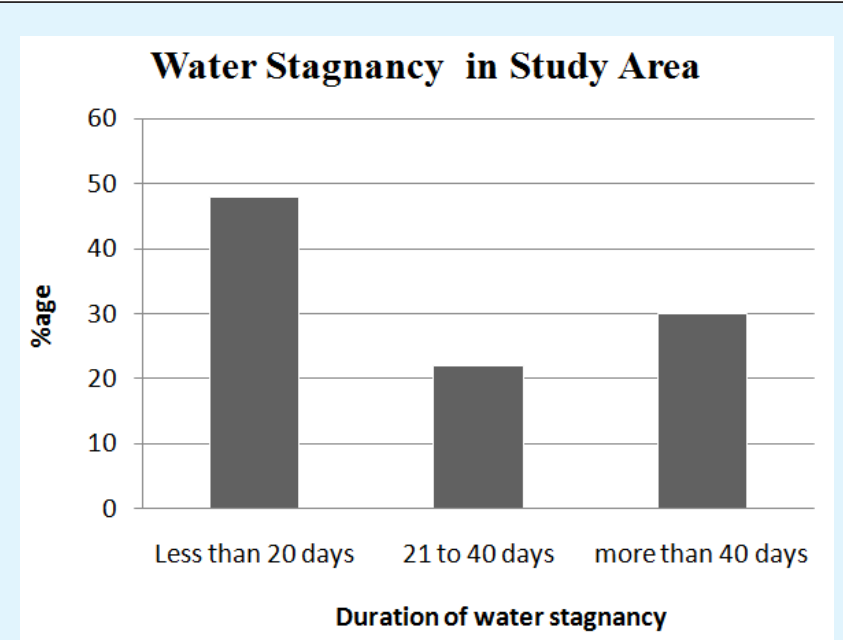

Figure 14: Showing water stagnancy period in study area.

$95 \%$ of the interviewers were saying that the 2010 flood causes human damages. Most of the peoples were drowned in the water as they were unaware of the flooding scenario in the River Indus (Figure 15).

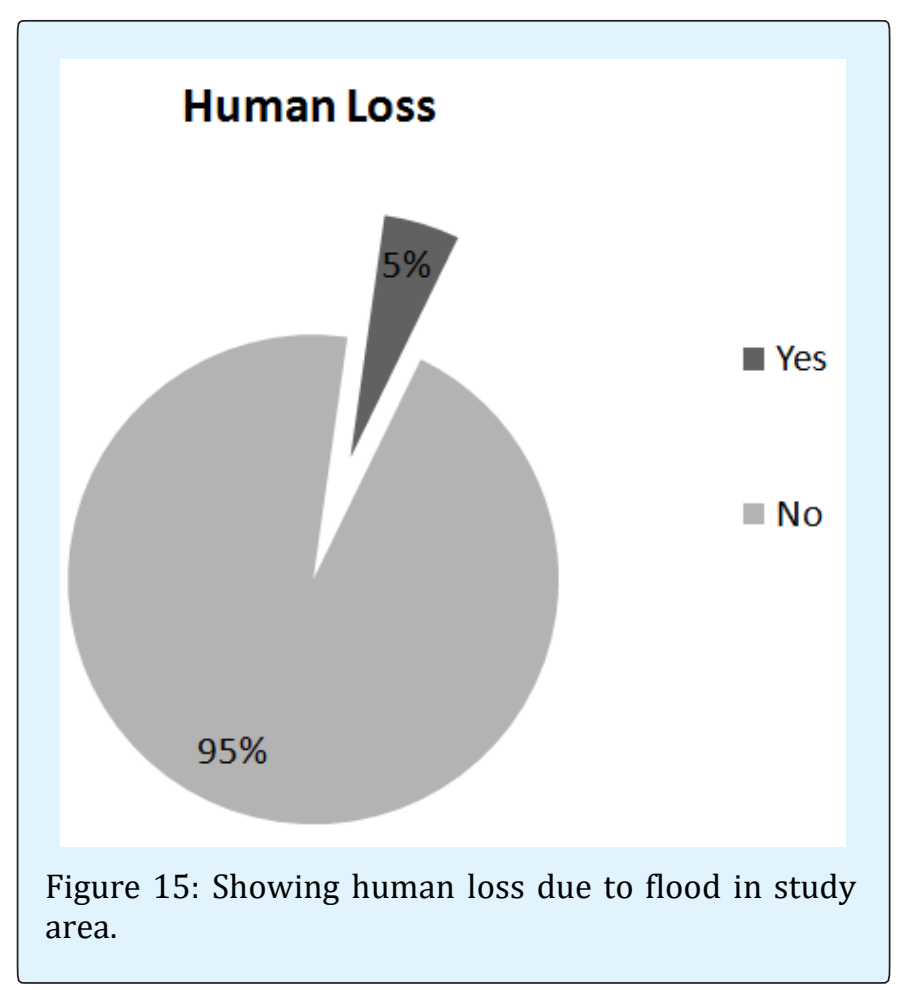


Shore Kot is a rural area where most of the people are uneducated and depends farming and cattle's. The $13 \%$ locals responses on cattle casualties during the 2010 flood while says their cattle's were not affected by flood (Figure 16).

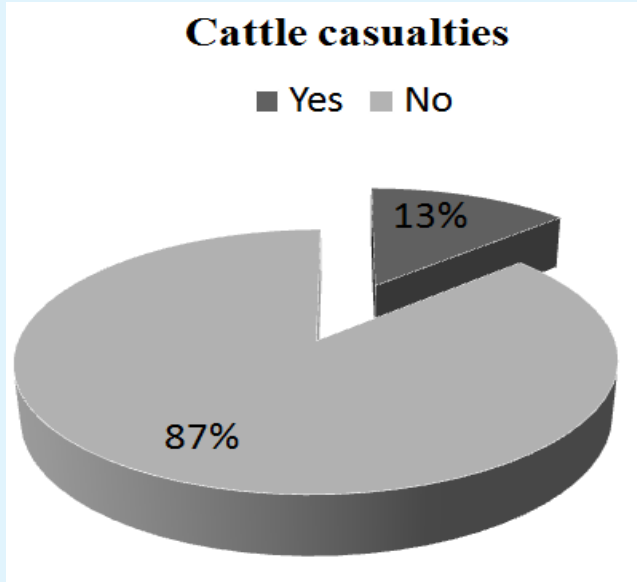

Figure 16: Showing cattle casualties in study area due to flood.

Flooding is a devastating condition which affects almost every section of a society. The 2010 flood in Shore Kot area affect the area badly, it also affects the stored grains in farmer's houses. Most of the people says that the damage to the stored grains were from 10 to 50 thousand rest of detail shown in Figure 17.

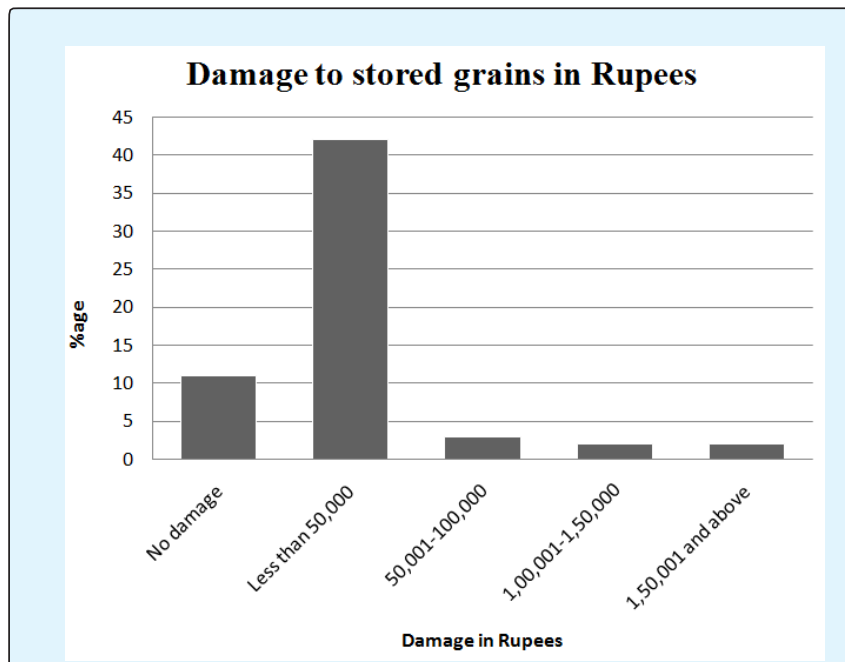

Figure 17: Showing damage to stored grains in Rupees.

Everywhere flood when affects infrastructure of that area occurs. In Shore Kot area flood affects the infrastructure including houses, roads, schools, irrigation canal, telephone line, and electricity line. Detail of damage to the infrastructure in the study area is shown in Figure 18.

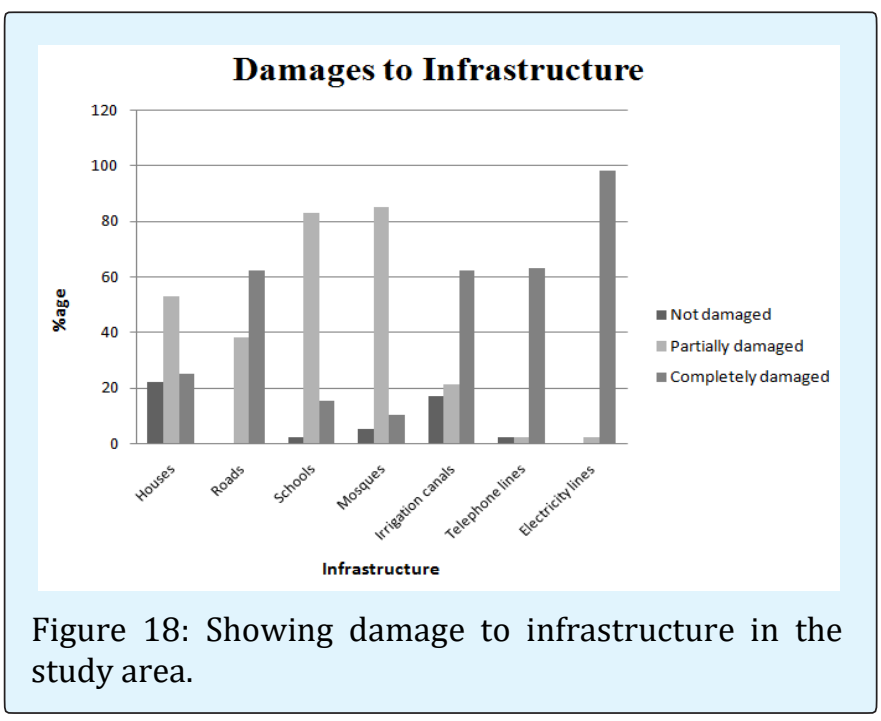

In final question the locals were asked about the solution how to overcome and minimize the destruction flood causes and how to prevent the flooding conditions. Most of the people suggests that building embankments of bank of Indus River will prevent the flood water coming to the populated and cultivated area. Some people also suggest that an alarming system should be made so that the local people will evacuate the area on time so that no human loss will occur. Some people also suggests that they should be trained of evacuation procedure during flooding condition while a few people need that they should be given the disaster relief fund (Figure 19).

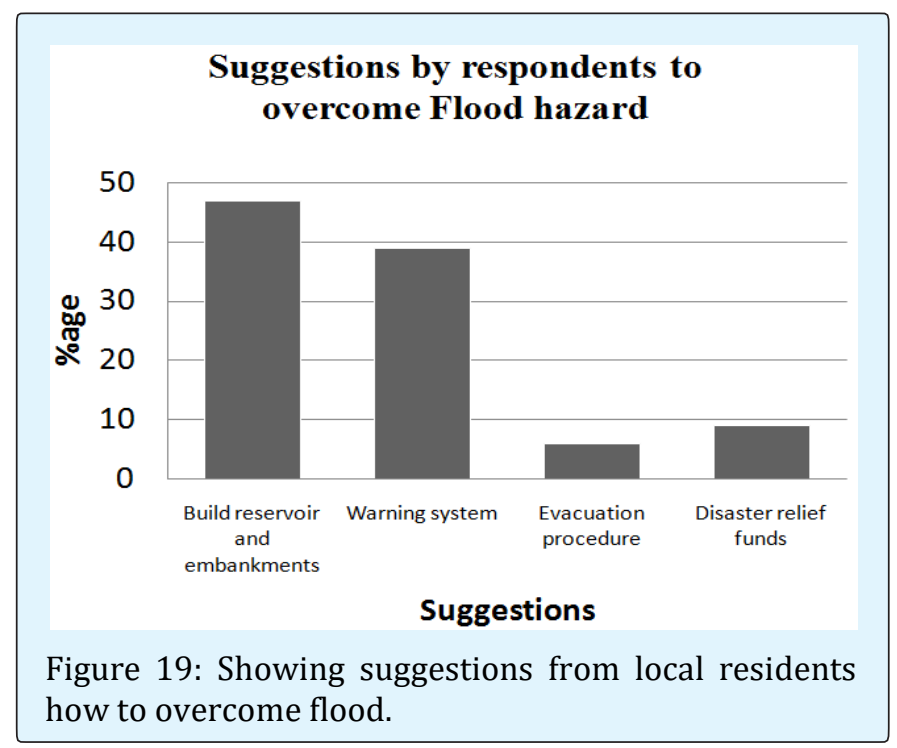




\section{Journal of Ecology \& Natural Resources}

\section{Results and Conclusion}

Pakistan is the one of those countries which are most affected by natural hazard and especially flood. The 2010 flood in Pakistan was described as the worst environmental disaster in Pakistan's history. In 2010 a devastating flood occurs in various places in Pakistan. Shore Kot area (DI Khan Kpk. The study area is vulnerable place to flood hazard. The main cause of flood in study area was heavy Monsoon rainfall and Noose water. There was lack of adequate warning system to inform people about flood, so that they could evacuate in time. The government also did not help the flood victims in evacuation. The procedure for Relief distribution suffered from favoritism by political leaders and mostly influential people had access to relief. There was also mismanagement during relief distribution. The financial support to the flood victims was insufficient for rehabilitation. The whole communication system was disturbed during flood 2010.Roads were washed away and many people remained in the flooded area.

Based on the results of this case study for Shore Kot area DI Khan District KP province, it can be concluded that geospatial technology provides the best potential to analyse and provide results required for prompt and effective decision-making on floods. This comprehensive flood hazard and flood shelters model developed in ArcGIS can be easily handled by novice GIS users. The object-based remote sensing technique and geographical information systems can be used to classify the extent of floods. Object-based classification systems allow different rules for different classes that can be used further for similar types of flood mapping. Natural flood disaster is common and cannot be stop. Remote sensing is an efficient tool for flood mapping and suitability analysis and can be useful for emergency response and disaster preparedness. As natural disaster increase in both intensity and severity around the world, the Asian countries continue to suffer a disproportionate number of hazard events and related losses in lives, infrastructure, stability and economic progress. Based on the results of this study for Shore Kot area DI Khan district KPK, it can be concluded that the study area is one of the most affected area and is still vulnerable to flood because of its geographic location. Remote sensing and GIS technology can provides the potential tool for prompt effective decision-making and management on flood.

\section{References}

1. Arambepola NMSI, Iglesias G (2009) Effective strategies for urban flood risk management. Paper presented at the Economic and Social Commission for Asia and the Pacific Expert Group Meeting on Innovative Strategies towards Flood Resilient Cities in, Asia-Pacific. Bangkok.

2. Brasdil R, Dobrovolny P, Kakos V, Kotyza O (2006) Historical and recent floods in the Czech Republic: Causes, seasonality, trends, impacts. Flood Risk Manage Hazards Vulnerability Mitigation Meas 67(6): 247-259.

3. Schanze J (2006) Flood risk management: A basic framework. Earth Environ Sci 67(1): 1-20.

4. Dutta K, Schuur EAG, Neff JC, Zimov SA (2006) Potential carbon release from, permafrost soils of North-eastern Siberia. Global Change Biology 12(12): 2336-2351.

5. Ahmad F, Kazmi SF, Pervez T (2011) Human response to hydro-meteorological, disasters: A case study of the Pakistan 2010 flash floods in Pakistan. J Geogr Reg Plannin 4(9): 518-524.

6. Atta-ur-Rahman, Khan AN (2011) Analysis of flood causes and associated socio-, economic damages in the Hindukush region. Nat Hazards 59(3): 1239-1260.

7. Hashmi HN, Siddiqui QTM, Ghumman AR, Kamal MA, Mughal HR (2012) A critical analysis of 2010 floods in Pakistan. Afr J Agric Res 7(7): 1054-1067.

8. Hashmi HN, Siddiqui QTM, Kamal MA, Mughal HR, Ghumman AR (2012) Assessment of inundation extent for flash flood management. Afr J Agric Res 7(8): 1346-1357.

9. FFC (2010) Ministry of water and power of Pakistan. Annual Flood Report, Pakistan.

10. Monsoon Contingency Plan (2012) Provincial Disaster Management Authority Khyber Pakhtunkhwa, Pakistan.

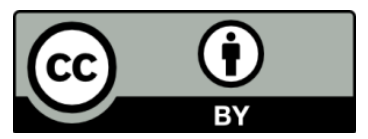

Mehmood M and Yaseen M. Impacts of 2010 Flood and GIS Mapping (A Case Study of UC Shore Kot) DI Khan, KP Province Pakistan. J Ecol \& Nat Resour 2018, Copyright@ Mehmood M and Yaseen M. 2(3): 000130 